\title{
A GUERRA INVISÍVEL
}

O Covid-19, um vírus que assustou e abalou o Globo terrestre e os moradores dos quatro cantos do mundo, por sua incógnita, por sua rapidez de contágio, a inexistência de tratamento e medicação e a consequente quantidade de mortes que trouxe, deixou bem claro que um inimigo invisível, poderia ser bem mais letal de que muitas guerras, deixando números catastróficos pelos Países onde fora propagado e ainda trazendo consequências futuras que infelizmente ainda não podemos mensurar.

Segundo a revista Superinteressante, publicada em 27/03/2020, tudo começou na Cidade Chinesa de Wuhan, mas que possivelmente já teria chegado há mais de 22 Países e atingido os cinco continentes, dentre estes os mais afetados foram o Europeu e o Americano.

$\mathrm{Na}$ Itália chegou a números alarmantes e preocupantes, segundo o G1, publicado em 25/03/2020, o País Europeu já somava mais de 7.500 mortes em todo o País, isso se deu em partes pela tardia imposição de medidas mais restritivas por parte do governo Italiano, que ao inicio da pandemia disse que os números relatados em outros Países, não eram confiáveis.

Já em terras Tupiniquins, diversos governantes atentos aos acontecimentos globais, decidiram através de Decretos, formalizar quarentenas, fechando escolas públicas e consequentemente as privadas, comércios e prestadores de serviços, deixando aberto apenas aqueles considerados essenciais à sobrevivência. Mesmo assim até o dia 16/03/2020, conforme edição publicada do "BOL notícias", uma ramificação do site UOL, já tínhamos até esta data um total de 13.717 novos casos confirmados de infecção e 667 mortes em razão do novo vírus.

Ao aprofundarmos nossa pesquisa, vimos que só o Estado de São Paulo, editou e publicou 12 Decretos, 07 deliberações do Comitê Administrativo Extraordinário e ainda 03 resoluções e 01 deliberação, todos relacionados ao combate e a prevenção do assustador vírus, isso até o dia 07/04/2020, conforme o site próprio do governo do Estado Paulista. A última medida foi estender provisoriamente a quarentena até o dia 22/04/2020, tais medidas tem como finalidade a diminuição do contágio e de possíveis mortes, pois, apenas em solo Paulista o vírus já vitimou 371 mortos, com 5.862 casos confirmados; das mortes efetivadas, as principais vitimas, ou seja, 313 são pessoas com mais de 60 anos, portanto, uma média de $85 \%$ das vítimas fatais são idosos, dados revelados pelo site "o documento", publicado em 08/04/2020.

Sendo assim, podemos perceber a rapidez na disseminação, a facilidade na transmissão e a inexistência de tratamento, trouxeram ao mundo um contágio de 1.447 .466 e um total de 83.471 mortes devido o contágio do Covid-19. Mesmo em meio a tantas noticias ruins, com a recente descoberta do tratamento através do cloroquina e outros tratamentos já foram possíveis a recuperação de 83.471 pacientes, números apresentados pelo site da universidade Johns Hopkins, dos Estados Unidos. 
É nesta seara que, podemos pontuar que a luta contra essa pandemia ainda se estende e pode se estender por vários dias ou meses, mas o que podemos definir é que começamos perdendo a batalha, mas já estamos, após incessantes lutas, discussões e estudos, revertendo os números e já conseguimos ver uma luz ao final do túnel, que nos permite antecipar uma possível vitória da guerra.

Por: José Carlos Machado - Pereira Barreto/SP 08/04/2020

\section{REFERÊNCIAS:}

https://super.abril.com.br/saude/mapa-mostra-a-abrangencia-do-

coronavirus-pelo-mundo-em-tempo-real/

https://covid19.min-saude.pt/

https://g1.globo.com/bemestar/coronavirus/noticia/2020/03/25/ha-um-mes-

italia-resistiu-a-tomar-medidas-mais-restritivas-contra-coronavirus-hoje-soma-75-milmortes.ghtml

https://www.bol.uol.com.br/noticias/2020/03/16/coronavirus-no-brasil-veja-onumero-de-casos-confirmados.htm

https://coronavirus.saude.gov.br/

https://odocumento.com.br/sp-registra-67-mortes-por-coronavirus-emapenas-um-dia/

https://www.saopaulo.sp.gov.br/spnoticias/decretos-do-governo-de-sp-commedidas-de-prevencao-e-combate-ao-novo-coronavirus/

https://br.ccm.net/faq/49174-coronavirus-acompanhe-em-tempo-real-onumero-de-casos-no-mundo

https://www.arcgis.com/apps/opsdashboard/index.htm|\#/bda7594740fd4029 $\underline{9423467 \mathrm{~b} 48 \mathrm{e} 9 \mathrm{ecf} 6}$

https://infograficos.oglobo.globo.com/sociedade/numeros-do-coronavirusno-brasil-e-no-mundo.html 